\title{
IMMIGRANT ENTREPRENEURSHIP IN ROMANIA: DRAWING BEST PRACTICES FROM MIDDLE EASTERN IMMIGRANT ENTREPRENEURS' EXPERIENGES
}

\author{
Ozgur Ozmen ${ }^{1}$, Raluca Mariana Grosu ${ }^{2 *}$ and Mariana Dragusin ${ }^{3}$ \\ ${ }^{1)}$ Nevşehir HBV University, Nevşehir, Turkey \\ ${ }^{2) 3)}$ Bucharest University of Economic Studies, Bucharest, Romania
}

\author{
Please cite this article as: \\ Ozmen, O., Grosu, R.M. and Dragusin, M., 2021. \\ Immigrant Entrepreneurship in Romania: Drawing \\ Best Practices From Middle Eastern Immigrant \\ Entrepreneurs' Experiences. Amfiteatru Economic, \\ 23(56), pp. 260-275.
}

DOI: $10.24818 / \mathrm{EA} / 2021 / 56 / 260$

\section{Article History}

Received: 15 September 2020

Revised: 30 October 2020

Accepted: 26 November 2020

\begin{abstract}
Migrant entrepreneurship represents a topic of a high societal and academic significance. For a host country, immigrant entrepreneurs' endeavours are, in many cases, an under-utilized lever for local and regional economic revival. Based on a complex field research carried out between July 2017 and December 2018, the present paper approaches immigrant entrepreneurship in Romania, with a particular focus on Middle Eastern immigrant entrepreneurs. Our multi-method qualitative field research - consisting of semi-structured interviews, observations and informal discussions - envisaged 97 immigrant businesses, targeting the analysis of the phenomenon from different perspectives: economic, social, cultural, political, and institutional. Aiming to draw best practices from the investigated Middle Eastern immigrant entrepreneurs' experiences, the research results outlined in this paper emphasize both descriptive and practical features. Migration-related particularities, entrepreneurs' profile, business obstacles, business practices, or perspectives on and comparisons of the Romanian business environment with the one in the origin country represent just few examples of aspects thoroughly approached in the paper.
\end{abstract}

Keywords: migration, entrepreneurship, immigrant entrepreneurship, immigrant entrepreneur, Romania, Middle Eastern immigrants

JEL Classification: F22, J15, M10, M20, O15

\footnotetext{
* Corresponding author, Raluca Mariana Grosu - e-mail: raluca.petrescu@ com.ase.ro
} 


\section{Introductory remarks with a focus on recent literature review}

In an extremely interconnected world, immigrant entrepreneurship represents a topic of a high societal and academic significance. Mainly referring to immigrants starting and developing businesses in the host country (Basu, 2006), immigrant entrepreneurship is the focus of an increasing number of scientific studies. Their outcomes have both important theoretical and practical dimensions, with a real capacity to favour improved decisions impact, at many levels.

Commonly approached also as ethnic and/or minority entrepreneurship, immigrant entrepreneurship as a field of study is supported by a wide, comprehensive and growing scientific literature. Strong economies in developed countries - like the United States of America, Canada, Australia or the United Kingdom, the Netherlands, or Germany, in Europe - that are also hosts to vast immigrant communities, are being investigated by immigrant entrepreneurship scholars. Considering recent works in the area, distinct research paths can be identified, such as: immigrants' entrepreneurial intentions; profile of the immigrant entrepreneur, their needs, motivations and potential; gender-related aspects; comparisons with native/local entrepreneurs both in terms of individual characteristics and business profile; importance of social networks in business development and performance; entrepreneurial orientation and business performance; policy implications and recommendations; impact factors on the development of immigrant entrepreneurship; etc. (Kitching, Smallbone and Athayde, 2009; Kloosterman, 2010; Ilhan-Nas, Sahin and Cilingir, 2011; Baycan, Sahin and Nijkamp, 2012; Neville et al., 2014; Dinu, Grosu and Saseanu, 2015; Kerr and Kerr, 2016; Vinogradov and Jorgensen, 2017; Bolzani and Boari, 2018; Rahman, 2018; De Luca and Ambrosini, 2019; Jones, Ram and Villares-Varela, 2019). Studies on immigrant entrepreneurship in less developed countries, are not so prominent in the scientific literature. For example, considering the case of Romania, the country investigated in this paper, research in the area of immigrant entrepreneurship is still in an incipient stage. There are few existing studies in the literature mainly focused on: descriptive issues of the entrepreneurial process of immigrant entrepreneurs; industry-related aspects; religion-related aspects; women immigrant entrepreneurship; etc. (Constantin, Goschin and Dragusin, 2008; Grosu and Saseanu, 2014; Grosu, 2015; Sharbek and Grosu, 2018).

Romania is highly acknowledged - by both scholars and practitioners - as an important provider of immigrants, especially for the European Union (EU) members, with a wellrepresented diaspora (Grosu and Constantin, 2013; Grosu and Dinu, 2016; Davidescu et al., 2017). Yet, this also represents an attractive destination country for immigrant population, especially for non-EU citizens, out of which many take the entrepreneurial path in the Romanian business environment. The highest number of newcomers in Romania are from the Republic of Moldavia. Other significant non-EU foreign communities are from China, Israel, or the Middle East. Arrivals of non-native Romanians from the EU countries are mainly registered from Austria, France, Germany, Hungary and Italy. In terms of entrepreneurship, Middle Eastern immigrant entrepreneurs, like Turkish, Jordanians, Syrians ones etc., are key players on the Romanian market. It is estimated that, especially Turks had a "significant contribution to the success of transition to a market economy, as well as to economic recovery, in post-1989 Romania" (Constantin, Goschin and Dragusin, 2008, p. 51).

Even if the existing body of works on immigrant entrepreneurship is very vast and provides various outcomes/ approaches on diverse regions and countries from all over the world, research on this topic in Romania is still in an incipient stage. Yet, this emerging field of 
study has great potential of development, offering scholars many research directions, worth exploring. Considering the previously framework, through our paper we aim at bringing a contribution, from theoretical perspective, to the development of the scarce scientific literature regarding the topic of immigrant entrepreneurship in Romania, in general, and that of Middle Eastern originated one, in particular. From a practical perspective, our work, has the potential to contribute to: shaping a clearer picture of the nature and content of the entrepreneurial processes initiated and carried out by immigrants in Romania; highlighting their role and raising awareness of the underutilized economic leverage they currently represent; promoting Middle Eastern immigrant entrepreneurs as inspiring role models, worth following, especially by other members of their community; highlighting Middle Eastern immigrant entrepreneurs' best practices in Romania, mainly to foster the entrepreneurial intentions of other immigrant communities.

In this sense, the present paper is structured into four main parts, introduction and conclusions included. 'Research methodology' is the next part of the paper, where we put forward main methodological aspects related to our research, closely followed by the section dedicated to this study's results.

\section{Research methodology}

This scientific work is developed based on a part of the outcomes of a multi-method qualitative field research carried out between July 2017 - December 2018, with the aim to provide a more complex and comprehensive image on the Middle Eastern immigrant entrepreneurship phenomenon in Romania. Our research targeted the analysis of this phenomenon considering relevant social, economic, political and institutional contexts, following the "mixed embeddedness" approach (Kloosterman, van der Leun and Rath, 1999).

Our investigated sample was composed of 97 businesses owned by Middle Eastern immigrant entrepreneurs in Romania, out of which: three big companies and 94 micro, small and medium sized enterprises. All of them were active in the capital-city region, respectively Bucharest-Ilfov. This is not a surprising fact as this is the most economically developed region in Romania, being 'host' not only to most of the companies at national level, but also of the immigrants, implicitly to immigrant business owners.

The lack of a clear evidence on immigrant entrepreneurs - defined as immigrants who initiate and develop a business in their host country (Basu, 2006) - in Romania, made impossible the access to a database with relevant information. The General Inspectorate for Immigration in Romania registers immigrants according to their migration purpose, but this does not further monitor if an immigrant with a clear business purpose did really start a business (Grosu, 2015). Furthermore, the national institution in charge with registering businesses, respectively the National Trade Register Office, only considers the foreign participation to capital in an enterprise, as a foreign-related aspect. This might refer to "enterprises started and developed - entirely, or partly - through the participation of private individuals or corporate entities with their stable residence or their headquarters outside Romania" (Oficiul National al Registrului Comertului, 2019). This approach reflects concepts related more to international entrepreneurship (e.g.: foreign investors), than to immigrant entrepreneurship. In such a framework, amplified by the high reluctance of immigrant entrepreneurs to take part in research, we approached the 'snowball' and the 'networking' sampling techniques to construct our sample. This was a very challenging process, with many obstacles encountered 
along the way. Even if one of the authors is known by the society of the mosques, some of the immigrant entrepreneurs were very suspicious concerning our study. They were convinced that our research was organized by the Romanian Secret Services, targeting the tagging of immigrant entrepreneurs in Romania. Thus, many of those approached during the sampling process did not want to be involved in generating the needed information, mainly claiming reasons like: lack of time to answer our questions; limited Romanian language knowledge; urgent need to arrive somewhere else, etc.

The main methods used to collect data from the targeted sample, were: face-to-face semistructured interviews, observations and informal discussions with the customers and/or employees of the investigated businesses. (Ozmen and Grosu, 2020)

The face-to-face semi-structured interviews carried-out with the immigrant entrepreneurs were mainly formal - being based on an interview guide - and lasted for around 40 minutes, each. Developed following the research's aim and objectives, the interview guide was first debated with scholars of entrepreneurship and pilot-tested on 3 immigrant entrepreneurs, its improved version being further applied in our research. Interviews were held in Romanian, but, also in Turkish or Arabic languages. In the latter case, a translator took part to the interview, too. Thus, the number of persons involved in the interview varied from two to four, depending on the case. Usually, the interviews took place at the owner's enterprise headquarter but there were also situations when several interviews were carried out in Turkish and Arabic mosques in Bucharest. Normally, interviews were not disturbed by external factors. However, in some cases, interruptions translated in: clients entering the place (store, restaurant, warehouse, etc.), employees entering the immigrant entrepreneur's office, phone calls, friends coming to approach the interviewee in the mosque, etc. (Ozmen and Grosu, 2020)

With regard to the observation method, our role was that of complete observers. In general, such actions were performed before having the interviews with the entrepreneurs and before developing the informal discussions with the employees and/or customers. We mainly targeted customers and employees to discover pertinent owner/ business related aspects. The observation regarding the first category aimed at the buyers' behaviour within the grocery stores, other retail stores, restaurants, etc., depending on the specific object of activity. We also observed the employees' conduct, along with the entire activity of the analysed business. The informal discussions lasted around five minutes with each individual. However, it is worth mentioning that we did not use the methods of 'observations' and/or 'informal discussions' in all the investigated businesses. (Ozmen and Grosu, 2020)

All our field research translated into many notes taken during the development of the abovementioned methods. However, information about how the whole data collection process went, about our own perceptions, feelings and thoughts, regarding non-verbal communication of investigated people, in each of the targeted entity were also recorded. All these notes generated invaluable information, part of it being further outlined in the paper.

\section{A comprehensive image on the Middle Eastern immigrant entrepreneurship phenomenon in Romania - main research results}

The investigated businesses were owned by Middle Eastern male entrepreneurs that immigrated in Romania between 1978 and 2015 (with the first 11 years, as part of the communist regime), from countries like: Turkey, Syria, Jordan, Iraq, Kuwait, and Lebanon. 
Their migration reasons were varied, ranging from studying, the desire to find a job or to become entrepreneur, to skipping the army enrolment, family reunification, tourism, avoiding the war and/or other political issues faced in the origin country, etc.

"My friends were here, my brother was here, my uncle was here ... So, I decided to come too.” (Turkish entrepreneur)

"Romania is a safe and beautiful country and I first came here as a tourist. I liked it so much as I did not want to return back home." (Turkish entrepreneur)

"The firm I've been working for in Turkey had a subsidiary in Romania and this is how I got here. After a while, the company was closed but I liked so much to be in Romania, that I did not want to go back to Turkey. I have searched for work in different places, but the result was not positive and, at the end, because I did not have any other choice, I became entrepreneur. Looking back now, I do not regret anything." (Turkish entrepreneur)

"My brother was in Romania. I decided to come here to offer a better future to my children." (Arab entrepreneur)

The time span the investigated immigrant entrepreneurs started a business in Romania, seems to be correlated too, in most of the cases, with their main reasons for migration. Most of the inquired Middle Eastern immigrant entrepreneurs, especially Turks, started their businesses in the same year when they have immigrated to Romania. However, there were incomers who also followed the entrepreneurial path after one year of immigration, or even up to 12 years. These are situations encountered mainly amid Arab immigrant entrepreneurs. Compared to Turks, that, generally, migrated to Romania with a strong business reason - no matter the period - Arabs mainly came to Romania, especially during the communist regime, for studying purposes. The most attractive industries for the immigrant entrepreneurs in our sample for business start-up and scale-up proved to be: commerce, production, construction, real estate, and HORECA. Both forms of opportunity and necessity-driven entrepreneurship were specified by the investigated Middle Eastern immigrants, the main mentioned "push" factor being the impossibility to find a job in the host country.

"The main reason I became entrepreneur was the fact that I did not find a job." (Arab entrepreneur)

With a dominant high level of education declared (university, masters and, in some cases, doctorate), the majority of responding entrepreneurs stated that education is a crucial provider of basic economic knowledge, paramount to their competences' and business skills' development. It is interesting to note that they've also appreciated the opportunity to learn foreign languages, especially English, considered a "must" to running their businesses. Furthermore, the respondents perceived that one of the main positive outcome of following university studies was the chance to expanding solid social networks. However, we've registered opposite opinions too, according to which entrepreneurship is not directly connected to education. Such assertions were mainly supported by interviewees who dropped out of school, or managed to pass only some of the primary education stages. From their point of view, one cannot learn entrepreneurship in school. For them, "entrepreneurship runs through their veins". It is something "they were just born with". They are consistent with the idea that entrepreneurship is more a native skill, which can be developed throughout life, while performing various activities and being around worth following role models. In many 
cases, close relatives, mainly males have inspired respondents' decisions to take the entrepreneurial path. Often, fathers were highly acknowledged as successful role models. Other representative figures with significant impact on their career, were their grandfathers, uncles and/or their brothers. In general, the masculine figures in their families seems to have put a strong mark on their evolution as entrepreneurs. Relevant samples of such previously presented opinions are provided below.

"I have followed university studies. [...] I have learned English. This helps me a lot while doing business." (Turkish entrepreneur)

"The things learned during the university helped me develop my business'vision." (Turkish entrepreneur)

"I have a university degree. [...] I consider that this didn't help me in my entrepreneurial career. All I know is from my father. My father taught me business. University only helped me to create additional social networks." (Turkish entrepreneur)

"My father determined me to become an entrepreneur. His influence was higher than the one education had on me." (Turkish entrepreneur)

"I always wanted to be an entrepreneur. This is my character." (Turkish entrepreneur)

"This was my dream since I was a child. [...] And I did it for being free." (Turkish entrepreneur)

"The university helped me to learn Romanian and about the Romanian culture, traditions, etc. It was my main achievement to become an entrepreneur in this country." (Arab entrepreneur)

"I have only graduated high school. This did not help me at all. My father was the only one who inspired me in doing business. Ever since I was 7, I started to work with him in his business. I have learnt from him how to do business. This is all I can do ... business. I don't know anything else." (Arab entrepreneur)

"Entrepreneurship is in my DNA, in my blood. It comes from my family." (Arab entrepreneur)

The majority of interviewees were not at their first entrepreneurial attempt. Other businesses - many of them in the same branch - were previously developed by the investigated Middle Eastern immigrant entrepreneurs. Furthermore, some of the respondents, before becoming entrepreneurs, were employees - in many of the cases, in the same area in which they've started their companies, either in Romania, or in their origin country. The way in which they talked about their businesses, their previous entrepreneurial endeavours and/or work experience, revealed strong dedication, passion and willingness to acquire knowledge, skills, experience and expertise in the area in which they run the business.

"Before starting my businesses, I knew everything about this market; I was hired in this branch before." (Turkish entrepreneur)

Generally, Turks have a business partner, of the same nationality, but there were also cases of Turkish immigrant entrepreneurs with Romanian shareholders. On the other hand, Arabs, usually, started their businesses by themselves. However, there were examples of multiple shareholding in the analysed Arab immigrant businesses, too. Somehow contradictory to traditional cultural beliefs, the partner is, in multiple cases, the entrepreneur's wife, often of 
Romanian nationality. Such a choice might be probably based on her Romanian language knowledge, and on the fact that she might be more accustomed with the host country's culture, fiscal system, and/or economic environment. As stated during the interviews, the lack of knowledge about many of the mentioned aspects represented important obstacles, for many immigrant entrepreneurs, Turks included. But, in most of the cases, these barriers were overcome with the help of legal and/or fiscal advisors.
"When I was in the process of starting my business, I did not know how to properly manage this, especially from a bureaucratic point of view. Therefore, I have hired a legal advisor." (Turkish entrepreneur)
"I have faced many obstacles because I did not know Romanian. I wasn't able to understand anything. But it all ended when I met my wife. She was my lifeline! She helped me a lot with my business and she became my business partner, as I wanted to show my gratitude to her." (Arab entrepreneur)

Other common challenges highlighted by the interviewed Middle Eastern immigrant entrepreneurs during their entrepreneurial career in Romania referred to: poor access to financial resources, human resource-related issues, bureaucracy, ambiguous institutional and legislative frameworks, corruption, difficulties in obtaining visas, and, even, discrimination.

"There is a lot of bureaucracy in Romania. One has to deal with different mentalities, and there is a low quality in many employees. Furthermore, when one starts a business, it is difficult to get any support and to have access to proper financing”. (Turkish entrepreneur)

"I had employees that were stealing from my business, were rude, and not very serious." (Turkish entrepreneur)

"I sometimes feel that we, as Arab entrepreneurs, do not benefit of similar 'rights' as Romanians do. If you are in a place (for example, an office) where there are also Romanians and you need something, Romanians have priority." (Arab entrepreneur)

"[...] I consider that there are too many controls performed by the Romanian authorities regarding my business." (Arab entrepreneur)

"I had a lot of problems before finding the right, trustworthy employees." (Arab entrepreneur)

According to collected answers, no matter the structure of the ownership, all the investigated Middle Eastern immigrant entrepreneurs seem to have generated new jobs, mainly occupied by Romanian employees. Only few of them declared having employees of other nationalities, like: Turks and Arabs, but also Bulgarians, Hungarians, Macedonian, or Moldavians. Furthermore, somehow, totally in contradiction with other scientific studies, most of our respondents did not place their businesses within their community, nor in communities with a high concentration of immigrants. Their choice was rather to set them in neighbourhoods that are not recognized for their immigrant character, but inhabited by Romanians. This translates into real economic contributions to those areas. So, the offer of products and/ or services of such an entrepreneur is usually not aiming first his own community of immigrants but the potential segments of Romanian customers. These are usually informed decisions, often based on professional feasibility studies and market research, providing relevant conclusions about the economic value of the business. However, as stated by those who 
started their businesses immediately after the fall of the communist regime, no studies were carried out back then. The Romanian market was "so free of competition and so full of customers willing to buy anything", that the development of such studies was not justified. Even more, almost all business started in that period were success granted.

"My business is addressing Romanians. I came here for them. They represent my market and I have previously investigated their needs and expectations for my products." (Turkish entrepreneur)

"I address to everyone interested in my services. I do not have any target market, considering my clients' diverse nationality. From this perspective, I can say I address to mass market." (Turkish entrepreneur)

“I target both Romanians and Turks.” (Turkish entrepreneur)

"Before starting my business, I knew the prices and the quality of the products my competitors sold." (Turkish entrepreneur)

"I have benefited from a feasibility study before starting the business." (Turkish entrepreneur)

"In my branch (bakery) there are a lot of Turkish entrepreneurs. I knew about them and about their background in the bakery industry in Turkey." (Turkish entrepreneur)

"I target both Romanians and Arabs.” (Arab entrepreneur)

"Before starting my business, I knew a lot about my market. [...] And I still know. I'm always researching about my competitors." (Arab entrepreneur)

"Before starting my business, I have studied the market. I have identified Romanians' needs and I have developed a business to satisfy their needs. I brought products for satisfying Romanians' needs." (Arab entrepreneur)

“When I started my business in 1991, I had exclusivity in my branch! What a great time! [...] No competition, many customers willing to buy all my products!" (Arab entrepreneur)

Another research finding from our sample is that immigrant entrepreneurs and the ethnic communities they are members of are adding to the cultural diversity through their specific customs and traditions, thus positively influencing the region's socio-cultural richness. They also often propose new products/services, many related to their national specificity, adding to a more diversified supply on the market. Almost all the investigated entrepreneurs stated that they developed their businesses in Romania based on the novelty principle. This translated not only in introducing new products/services but also in providing innovative production and selling technique and new approaches in business model design.

"I have a very well-developed logistic system and I offer to my clients integrated solutions" (Turkish entrepreneur)

"I have introduced new, trendy models in clothing." (Turkish entrepreneur)

“We always develop new products, of high quality, and our prices are very affordable." (Arab entrepreneur) 
In order to strengthen their effectiveness, some respondents admitted to having searched for additional support, other than the regularly available one for all Romanian entrepreneurs. Aware of potential ethnic-related hindrances some immigrant entrepreneurs have joined specific business associations. This is mainly the case of the Turkish entrepreneurs who are part of TIAD (Turkish Businessmen Association in Romania), the most representative business association of foreign entrepreneurs in Romania. Forms of support, especially moral and financial, was also received from families, friends and/or business partners. Furthermore, correlated somehow with their religion and culture, very often, Divinity was mentioned as the main supporter by many respondents. In terms of financial aid, most of the investigated Middle Eastern immigrant entrepreneurs started their business mainly on their own savings, raised especially from their origin countries.

The immigrant interviewees' perception on the ease of living and doing business in Romania is divided, probably mainly due to national culture's specificity, language and writing included. A number of respondents in our sample signalled some feelings of frustration. For example, some Syrian immigrant entrepreneurs expressed an intention to return to their origin country. Though they've admitted that this would be impossible, especially because of the threatening war. Even if Syria was perceived by most of the investigated Syrian immigrant entrepreneurs as having a friendlier business environment compared to Romania, with better fiscal policy, lower taxation schemes and easier accounting policy, the on-going war in their country still keeps them in Romania.

As expected, in the case of Arab immigrant entrepreneurs' perception, the Romanian business environment has significant and often problematic differences in comparison with their native country. However, as revealed by many, those having a Romanian wife can easier overcome some of the fiscal and regulatory issues, by assigning her an important role in their business.

On the contrary, the vast majority of Turkish respondents unveiled a more positive/ friendlier attitude, stating that there are no major distinctions between the two business environments, Turkish and Romanian. They had no restrains in emphasising many similarities, for example accounting rules, which makes easier for Turkish entrepreneurs to run businesses in Romania, compared to Arabs. Furthermore, the historical relationships between Romanians and Turks are likely to explain a more flexible, adaptable, and more open displayed attitude of inquired Turkish entrepreneurs towards the host country's culture. However, in some cases, heavier fiscal and regulatory constraints and sharper bureaucracy were reported by Turkish interviewees. Furthermore, official entities' control rounds in Romania were assessed as more complex and frequent compared to the ones usually performed in Turkey.

Just like Romanian entrepreneurs themselves, many of our immigrant respondents' complains are related to the legal framework. Despite its thick structure, they all blame its high degree of interpretability, its rapid and frequent changes in both content and form, thus generating a lot of confusion and, in some situations even corruption.

Several "pull" factors have been highlighted by the immigrant respondents. For instance, Romania is considered to having a market with a lower competition compared to the one in the interviewees' countries of origin, to provide clients that are easier to satisfy and employees that can be paid at lower salaries, however, not quite trustworthy. Furthermore, access to capital is less demanding in Romania, and the required start-up capital is much lower compared to the one needed in Turkey, for example, as expressed by the investigated 
Middle Eastern immigrant entrepreneurs. Other host country's strengths, distinctly pointed out by our respondents refer to: Romania's excellent geographical position, its status of an EU and NATO member, its safety and stability, and its rich and inclusive culture.

"The Romanian legal framework has low stability. I consider that in Turkey it is easier to start a business. I know the laws. In Romania, bureaucracy is very high.” (Turkish entrepreneur)

"There are many controls in Romania and, most of them, are very intense. In Turkey, the competition is higher. In Romania, the profit is higher." (Turkish entrepreneur)

“After Romania's accession to the EU, things have improved a lot. [...] The business environment in Romania is safer and the competition is not very high, especially when compared to Turkey.” (Turkish entrepreneur)

"Compared to Turkey, Romania is more peaceful, the stress level is lower, and my time management is better. On the other hand, the business environment in Turkey is more developed." (Turkish entrepreneur)

"If you know the language and if you understand the bureaucracy, you can do great business in Romania. It is better than in Turkey; the profit is higher." (Turkish entrepreneur)

"Syria does not have a free market. Romania offers a free market. Romania is better for business.” (Arab entrepreneur)

"In Syria, taxes are lower, but the bureaucracy and the people are the same." (Arab entrepreneur)

"In Syria, everything is better, but the political conditions are bad. When the war ends, I will go back to Syria to develop a business there. I want to go back home, but the war is a big problem." (Arab entrepreneur)

"In Syria, trust is very important. You can do business just based on trust. People are very correct in Syria. In Romania, people are not always trustworthy, and it is still a lot of corruption." (Arab entrepreneur)

"In Lebanon the controls are lighter, and the law is more permissive." (Arab entrepreneur)

"In Egypt, the regulatory frame is more stable and there are fewer taxes." (Arab entrepreneur)

"In Egypt, you receive a lot of subsidies, especially for agriculture. As producer, is better to develop businesses in Egypt, especially in the agriculture area, than in Romania where agriculture is not so valued." (Arab entrepreneur)

"In Romania, the market is bigger than in Jordan, but in Jordan controls and fines are lighter. In Romania, whenever you get a control, for sure, you will get a fine." (Arab entrepreneur)

"Iraq has a greater market compared to Romania, but in Iraq things are not going very well." (Arab entrepreneur)

"In Kuwait, the market is smaller, and the competition is higher." (Arab entrepreneur) 
Based on their entrepreneurial experience and considering all the previously expressed opinions, a series of measures were suggested by the investigated Middle Eastern immigrant entrepreneurs in Romania, able to improve their entrepreneurial endeavours. Most of them are valid for all types of entrepreneurs active on the Romanian business environment. Among them, the most frequently mentioned refer to: reducing bureaucracy, lowering taxes, decreasing credits' interest rates to ease access to finance, stabilising the legal framework, especially by complying to the EU's recommendations.

"Controls accomplished by different authorities should be stricter and fewer. [...] Some authorities' attitude, sometimes, makes you became corruptible, when bribery is encouraged, and, if you become corrupt you are afterwards punished in accordance with the law. [...] These practices should be stopped. Bribery is not allowed in a solid entrepreneurial system." (Turkish entrepreneur)

“Bureaucracy needs to be reduced.” (Turkish entrepreneur)

"Credits should have lower interests.” (Turkish entrepreneur)

“Taxes should be lowered.” (Turkish entrepreneur)

"There should be developed a uniform system for everyone, in accordance with the EU's requirements, and not to change it very often. Romania should better protect its entrepreneurial environment. All the entrepreneurs must be treated in an equal manner." (Turkish entrepreneur)

"The process of getting a credit should be easier, employees should have insurances (the process for getting them for the employees should be easier), and the certifications should be easier to obtain." (Turkish entrepreneur)

"Romania should lower corruption, improve justice, and properly apply the EU's recommendations." (Arab entrepreneur)

"Laws should be better, more encouraging for entrepreneurs and for investors." (Arab entrepreneur)

"In their first years of business, immigrant entrepreneurs should be supported by Romanian authorities, especially from juridical point of view." (Arab entrepreneur)

\section{Concluding remarks: outlining best practices specific to Middle Eastern immigrant entrepreneurs}

Based on various results of a multi-method qualitative field research, this paper aimed at contributing to a more complex and comprehensive image on the Middle Eastern immigrant entrepreneurship phenomenon in Romania. In this final section, the main conclusions of our research are also crystallized into a best practices guide.

Middle Eastern immigrant entrepreneurs are significant players on the Romanian market, contributing to the total added value in the country's economy. Their efforts, business initiatives are worth to be promoted as strong role models for other immigrants and their communities. Both forms of opportunity and necessity-driven entrepreneurship have been identified among the investigated Middle Eastern immigrants. The most frequent mentioned "push" factor was the impossibility to find a job in the host country. 
The investigated businesses were owned by Middle Eastern male entrepreneurs that immigrated in Romania between 1978 and 2015, from Turkey, Syria, Jordan, Iraq, Kuwait, or Lebanon. Romania's geographical position, its EU and NATO member status, its safety and stability, along with its diverse and inclusive culture represented strong arguments in choosing it as a destination country. Furthermore, from a business perspective, when compared to their origin countries, Romania is considered to: have a market with a lower competition; provide clients that are relatively easier to satisfy and employees that can be paid at lower salaries; offer easier access to capital; require a lower start-up capital. The reasons for migration were varied, ranging from studying, the desire to find a job or to become entrepreneur, to family reunification, tourism, etc. However, especially when compared to Arabs, Turkish immigrant entrepreneurs had clearer business-related immigration reasons in Romania. The main industries attractive for the investigated immigrant entrepreneurs to start and/or develop their businesses were: commerce, production, construction, real estate, and HORECA. In terms of shareholding, usually, Turks have a business partner - in most of the cases of Turkish nationality. However, Romanian shareholders were also encountered in businesses ran by Turkish immigrant entrepreneurs. On the other hand, in general, Arabs, started their business mostly by themselves.

Almost all the investigated entrepreneurs were not at their first entrepreneurial attempt, and many of them were also having previous experience as employees, usually in the same branch. Thus, the experience and expertise in the same field of activity, was perceived as an advantage by many of our respondents.

With a high level of education, most of the investigated immigrant entrepreneurs considered education an important provider not only of basic economic and foreign languages knowledge but also a provider of an appropriate context for business skills development. Knowing a foreign language is considered extremely important when doing business. Other key aspect strongly considered for the entrepreneurial endeavour was the social networks. This was a focus for many inquired immigrant entrepreneurs, even during their university, master and/or doctorate studies. However, there were also entrepreneurs who dropped out of school, or who have low level of education, primarily among those who strongly believe that entrepreneurship success is not education related. Role models are perceived as very important in entrepreneurship processes by the interviewees. Mostly masculine figures in the family - fathers, grandfathers, uncles and/or brothers - have been indicated as powerful influencers on the respondents' decisions to take the entrepreneurial path.

The investigated immigrant entrepreneurs who started their business immediately after the fall of the communist regime - in a market free of competition, with an enormous unsatisfied demand for products and services - guided themselves only by their strong native entrepreneurial spirit and by empirical basis. Such an approach was less valid for more recent immigrant entrepreneurship practices. Professional feasibility studies and market research were previously designed to support improved business decisions.

Through the activities carried out, the investigated Middle Eastern immigrant entrepreneurs had a positive contribution to the development of the Bucharest-Ilfov region, at various levels: economic, social and cultural. Relevant examples in this regard include: new jobs creation - mainly for Romanians, but also for Turks, Arabs, Bulgarians, Hungarians, Macedonians and Moldovans, paying taxes, introducing new, innovative products/services on the Romanian market, the implementation of new managerial styles, enrichment of the general fund of customs and traditions with those specific to the culture of the country of

Vol. $23 \cdot$ No. $56 \cdot$ February 2021 
origin, etc. Yet, various obstacles were perceived by the investigated immigrant entrepreneurs during their entrepreneurial career: language and culture barrier, poor access to financial resources, human resources-related issues, bureaucracy, difficult fiscal system, unclear legislative framework, corruption, difficulties in obtaining visas, and, even, discrimination. The method invoked as being frequently used to overcome such obstacles was to turn to legal/tax advisers, in the case of Turkish respondents, respectively to co-opt as a business partner the Romanian wife, in the case of Arabs. Families, friends and/or business partners were mentioned by the majority of those interviewed as representing major moral and financial support. In addition, many respondent entrepreneurs suggested specific measures that could help create a more immigrant-friendly business environment in Romania: alleviating bureaucracy, lowering taxes, decreasing credits' interest rates to ease access to finance, stabilising the regulatory framework, especially by complying to the EU's recommendations.

The results of this study are converging to the conclusion, similar to others in the field, that entrepreneurship is a viable career option, regardless of the motivation or timing of the person's decision to migrate. Exploiting the various business opportunities identified in the host country could result in the creation of profitable businesses by immigrants.

In compliance with the paper regarding "Evaluation and Analysis of Good Practices in promoting and supporting Migrant Entrepreneurship", developed at the EU level (European Commission, 2016) and with the main results of our research, we designed a guide summarizing best practices, drawn mainly from the experiences of Middle Eastern immigrant entrepreneurs included in our research sample and that are not resource intensive. These are circumscribed to the following seven, out of the ten "dimensions in action", specified by the guide (European Commission, 2016): "networking"; "legal advice"; "individual business support"; "group business training"; "mentoring"; "access to finance"; "language and cultural sensitivity". The guide should constitute a benchmarking tool able to contribute to fostering entrepreneurship amid immigrant communities in Romania further on.

- Using/extending opportunities to network with other immigrant entrepreneurs and/or Romanian entrepreneurs, including potential providers and customers; this would favour access to new information and knowledge, stimulating business set-up and scale-up efforts.

- Accessing available schemes/formal entities responsible for the enhancement of entrepreneurship in general, and that of immigrant entrepreneurship in particular.

- Carefully periodically checking, the institutional and legal frameworks in order to easily comply with the host's country regulations; request for professional support if necessary.

- Exploring the help that one or more family members or non-members could provide, based on trust and complementarity, through their experience and knowledge, in the entrepreneur's efforts to overcome the inherent administrative and socio-cultural challenges.

- Encourage group training to share and exchange acquired experiences, especially regarding host country related aspects; try to preserve/pass traditional ethnic crafts' knowhow to support/build your distinct brand.

- Consider employing both ethnic and native persons in your area. 
- Take into consideration strong role models of former and current successful entrepreneurs, as inspiring and powerful factors influencing entrepreneurial decisions in immigrant communities.

- Consider a mentoring partnership, both as mentee seeking for complementary support and/or mentor sharing with ethnic community members accumulated experience as established entrepreneur within the Romanian business environment.

- Consider multiple business financing sources, including alternative ones (like crowdfunding, Business Angels etc.) and other mainstream support schemes for entrepreneurs, encompassing guarantee funds too.

- Find viable ways to reduce language barriers in the host country, by taking native language informal and formal courses, especially regarding business related terminology.

This narrow ethnic group approach should be integrated into a more holistic one at local, regional or national levels, to properly cover all the ten "dimensions in action" - "visibility", "facility provision" and "impact" included - consistent with the guide book's recommendations (European Commission, 2016). It would encourage the design of specifically tailored programs providing multi-dimensional support, like other successful ones in Europe, capable of generating positive spill overs, inside and outside the immigrant communities in Romania.

\section{References}

Basu, A., 2006. Ethnic minority entrepreneurship. In: M. Casson, B. Yeung, A. Basu and N. Wadeson eds., 2006. The Oxford Handbook of Entrepreneurship. New York: Oxford University Press, pp.580-600.

Baycan, T., Sahin, M. and Nijkamp, P., 2012. The urban growth potential of secondgeneration migrant entrepreneurs: A sectoral study on Amsterdam. International Business Review, [e-journal] 21(6), pp.971-986. https://doi.org/10.1016/j.ibusrev.2011.11.005.

Bolzani, D. and Boari, C., 2018. Evaluations of export feasibility by immigrant and nonimmigrant entrepreneurs in new technology-based firms. Journal of International Entrepreneurship, [e-journal] 16, pp.176-209. DOI: 10.1007/s10843-017-0217-0.

Constantin D.L., Goschin Z. and Drăgușin M., 2008, Ethnic entrepreneurship as an integrating factor in civil society and a gate to religious tolerance: a spotlight on Turkish entrepreneurs in Romania. Journal for the Study of Religions and Ideologies, 7(20), pp.49-79.

Davidescu, A.A.M., Strat, V.A., Grosu, R.M. and Zgura, I.D., 2017. Determinants of Romanians' Migration within the European Union: Static and Dynamic Panel Gravity Approaches. Amfiteatru Economic, 19(46), pp.621-639.

De Luca, D. and Ambrosini, M., 2019. Female immigrant entrepreneurs: more than a family strategy. International Migration, [e-journal] 57(5), pp.201-215. https://doi.org/10.1111/ imig. 12564.

Dinu, V., Grosu, R.M. and Saseanu, A.S., 2015. Romanian Immigrant Entrepreneurship: Utopia or Reality? An Overview of Entrepreneurial Manifestations of Romanian Immigrants in Andalusia, Spain. Transformations in Business \& Economics, 14(1(34)), pp.48-64. 
European Commission, 2016. Evaluation and Analysis of Good Practices in promoting and supporting Migrant Entrepreneurship. [online] Available at: <https://ec.europa.eu/ easme/sites/easme-

site/files/documents/guide_book_promoting_and_supporting_migrant_entrepreneurship. pdf> [Accessed 2 June 2020].

Grosu, R.M. and Dinu, V., 2016. The migration process of Romanians to Andalusia, Spain. Focus on socio-economic implications. $E \& M$ Ekonomie a Management, [e-journal] 19(2), pp.21-36. http://dx.doi.org/10.15240/tul/001/2016-2-002.

Grosu, R., 2015. Dynamics of immigrant entrepreneurship in Romania. Economy of Region, 2, pp.172-182.

Grosu, R.M. and Saseanu, A.S., 2014. Immigrant entrepreneurship - a challenge to commodity science in the age of globalization. In: C. Andrzej and S. Jerzy eds., 2014. Commodity Science in Research and Practice - Achievements and challenges of commodity science in the age of globalization. Krakow: Polish Society of Commodity Science, pp.119-130.

Grosu, R.M. and Constantin, D.L., 2013. The International Migration in the EU. A Descriptive Analysis Focused on Romania. Acta Universitatis Danubius - Oeconomica, 9(4), pp.:306-319.

Kerr, S.P. and Kerr, W.R., 2016. Immigrant Entrepreneurship. Harvard Business Scholol. Working Paper 17-011. (NBER Working Paper Series, No. 22385, July 2016.) [online] Available at: <https://www.hbs.edu/faculty/Pages/item.aspx?num=51304> [Accessed 22 September 2019].

Kitching, J., Smallbone, D. and Athayde, R., 2009. Ethnic Diasporas and Business Competitiveness: Minority-Owned Enterprises in London. Journal of Ethnic and Migration Studies, [e-journal] 35(4), pp.689-705. https://doi.org/10.1080/ 13691830902765368.

Kloosterman, R.C., 2010. Matching opportunities with resources: A framework for analyzing (migrant) entrepreneurship from a mixed embeddedness perspective. Entrepreneurship and Regional Development, [e-journal] 22(1), pp.25-45. https://doi.org/ 10.1080/08985620903220488.

Kloosterman, R., Van der Leun, J. and Rath, J., 1999. Mixed embeddedness: (in)formal economic activities and immigrant businesses in the Netherlands. International Journal of Urban and Regional Research, 23(2), pp.253-267.

Ilhan-Nas, T., Sahin, K. and Cilingir, Z., 2011. International ethnic entrepreneurship: antecedents, outcomes and environmental context. International Business Review, [e-journal] 20(6), pp.614-626. 10.1016/j.ibusrev.2011.02.011.

Jones, T., Ram, M. and Villares-Varela, M., 2019. Diversity, economic development and new migrant entrepreneurs. Urban Studies, [e-journal] 56(5), pp.960-976. https://doi.org/ 10.1177/0042098018765382.

Neville, F., Orser, B., Riding, A. and Jung, O., 2014. Do young firms owned by recent immigrants outperform other young firms?. Journal of Business Venturing, [e-journal] 29, pp.55-71. DOI: 10.1016/j.jbusvent.2012.10.005.

Oficiul National al Registrului Comertului, 2009. Societati cu participare straina la capital. [online] Available at: <https://www.onrc.ro/index.php/ro/statistici?id=254> [Accessed 19 November 2019]. 
Ozmen, O. and Grosu, R.M., 2020. Business in a Foreign Country: A Contextual Analysis of Immigrant Entrepreneurship and Their SMEs. In: Thrassou, A., Vrontis, D., Weber, Y., Shams, S.M.R. and Tsoukatos, E., 2020. The Changing Role of SMEs in Global Business. Vol. II: Contextual Evolution Across Markets, Disciplines and Sectors. Book Series: Palgrave Studies in Cross-disciplinary Business Research, In Association with EuroMed Academy of Business. Palgrave Macmillan, pp.39-60. DOI 10.1007/978-3-03045835-5.

Rahman, M.M., 2018. Development of Bangladeshi immigrant entrepreneurship in Canada. Asian and Pacific Migration Journal, [e-journal] 27(4), pp.404-430. https://doi.org/ 10.1177/0117196818810096.

Sharbek, N. and Grosu, R.M., 2018. Entrepreneurship: nurturing self-esteem in a new generation of immigrant Arab women in Romania. Romanian Journal of Regional Science, 12(2), pp.70-91.

Vinogradov, E. and Jorgensen, E.J.B., 2017. Differences in international opportunity identification between native and immigrant entrepreneurs. Journal of International Entrepreneurship, [e-journal] 15(2), pp.207-228. DOI: 10.1007/s10843-016-0197-5. 